
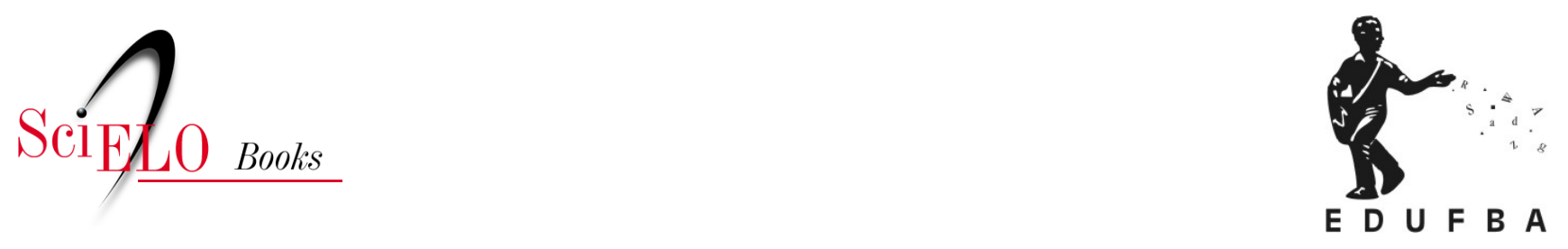

\title{
A visualidade singular do teatro de Shakespeare
}

\author{
Eduardo Tudella
}

\section{SciELO Books / SciELO Livros / SciELO Libros}

TUDELLA, E. A visualidade singular do teatro de Shakespeare. In: A luz na gênese do espetáculo [online]. Salvador: EDUFBA, 2017, pp. 81-114. ISBN: 978-85-232-1858-4.

https://doi.org/10.7476/9788523218584.0004.

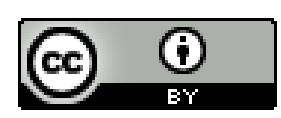

All the contents of this work, except where otherwise noted, is licensed under a Creative Commons Attribution $\underline{4.0 \text { International license. }}$

Todo o conteúdo deste trabalho, exceto quando houver ressalva, é publicado sob a licença Creative Commons Atribição 4.0.

Todo el contenido de esta obra, excepto donde se indique lo contrario, está bajo licencia de la licencia Creative Commons Reconocimento 4.0. 


\section{A VISUALIDADE SINGULAR DO TEATRO DE SHAKESPEARE}

Em procedimento comum, e até certo ponto esperado, os estudos da luz na cena são iniciados com discussões acerca da atividade teatral renascentista na Itália ou, quando muito, contemplando o teatro eclesiástico que a antecede. Aí devem ser incluídos espetáculos religiosos dos quais se tem notícia em relatos que datam do século X, de acordo com Alois M. Nagler (1952), eventos que ocorreram durante a Idade Média, em países da Europa.

A decisão de iniciar os mencionados estudos da luz pelo Renascimento italiano pode ser justificada em evidências que indicam a presença das primeiras ocorrências da aplicação de luz artificial - com o objetivo de promover visibilidade para a cena - em igrejas, catedrais, e, posteriormente, em teatros dos períodos citados. Podia-se até encontrar espetáculos nos quais o uso de luz artificial sugeria noite e/ou escuridão. Textos que apresentam tal característica sugerem uma convenção simples, mas sofisticada, indicando que a observação atenta de sinais 
deixados pela dramaturgia, por vezes muito sutis, pode revelar a interação da práxis cênica com a visualidade. Tais sinais podem estar contidos em circunstâncias que parecem óbvias, correndo o risco de serem desconsiderados.

A abordagem de aspectos particulares da obra de William Shakespeare (1564-1616), no momento inicial da presente discussão, é justificada por uma compreensão particular da sua dramaturgia, ou seja, trata-se de textos teatrais que já trazem inúmeros indícios da presença da luz na sua própria constituição. Portanto, a obra de Shakespeare ganha relevância para o presente trabalho, à medida que, ocorrendo já no século XVI - quando o teatro italiano havia instituído o uso da luz artificial na cena -, ele constrói a visualidade do seu espetáculo em consistente parceria com a dramaturgia, dispensando compromissos evidentes com aparatos de luz artificial.

Ao elaborar uma introdução ao contexto no qual Shakespeare escreveu, o presente trabalho considera desnecessário produzir um texto mais extenso sobre detalhes circunstanciais da sua obra e sublinha estrategicamente elementos pertinentes e relevantes para a abordagem em curso. Serão comentadas, especialmente, Hamlet (The tragedy of Hamlet-prince of Denmarke), A tempestade (The tempest) e Rei Lear (The tragedy of King Lear), ${ }^{1}$ na versão do Primeiro Fólio (First folio, 1623), com algumas passagens pelo Quarto $I,{ }^{2}$ para problematizar indícios de presenças da luz desde a ideia inicial de um espetáculo.

A citação de trechos das peças torna-se indispensável para alicerçar os argumentos aqui elaborados. As traduções para as obras de Shakespeare que aqui aparecem são de Bárbara Heliodora, exceto para o caso de Hamlet, cuja tradução é de Anna Amélia Carneiro de Mendonça.

Anne Surgers (2005b, p. 93, tradução nossa) define aquilo que se conhece como Teatro Elisabetano: "O traço explícito da complexa correlação entre teatro e poder". ${ }^{3}$ A autora inclui em tal assertiva aspectos do amparo provido pelos nobres e pela própria rainha aos atores e autores, oficialmente acordado em 1574. Alguns comentadores registram o acesso da Rainha Elisabeth ao poder (1558), como o início do período. Surgers (2005b, p. 94, tradução nossa), entretanto, pondera:

\footnotetext{
1 Hamlet e Rei Lear, respectivamente, em português.

2 O termo quarto, do latim, refere-se originalmente à dimensão do papel; uma folha dobrada para se alcançar duas partes iguais era conhecida como fólio. Ao ser novamente dobrada, resulta quatro folhas com, em geral, 10'x6'" [254 cm x $203 \mathrm{~cm}$ ]. Quando se trata de Shakespeare o termo quarto pode indicar, por vezes, cópias incompletas ou revisadas. O Primeiro Fólio, publicado em 1623, é reconhecido como importante documento para o estudo da dramaturgia de Shakespeare.

3 "[...] la trace explicite de la corrélation complexe entre théâtre et pouvoir [...]."
} 
Com efeito, em 1572, um decreto do Parlamento, a Lei para a punição de Vagabundos, exigia que cada companhia de atores estivesse sob a proteção de um nobre ou dignitário da justiça. Sem tal proteção, que os concedia o direito ao trabalho, os atores eram tratados como vagabundos, e, como tal, sujeitos a pena de prisão ou até mesmo ao pelourinho. Em 1572, James Burbage obteve a proteção do Conde de Leicester para sua companhia, e dois anos depois, a da própria rainha. ${ }^{4}$

Por outro lado, da oposição puritana à monarquia derivava - ou incluía - grave desaprovação ao teatro, culminando com uma ação definitiva do Parlamento que aprovou, em 2 de setembro de 1642, a interdição de qualquer representação teatral. Era o fim oficial do período teatral no qual Shakespeare elaborou sua obra.

Ele teria se transferido para Londres, no final da década de 1580, período no qual a atividade teatral londrina se intensificava. James Burbage (ca.1531-1597) pai de Richard Burbage (1568-1619), que seria o principal ator nos espetáculos de Shakespeare - já havia construído, em 1576, numa sociedade com o seu cunhado John Brayne, a casa de espetáculos que batizou como O Teatro (The Theatre). Na opinião de Surgers, considerando que a expressão mais usada àquela época na Inglaterra seria "casa de espetáculos" (playhouse), Burbage teve motivos particulares para escolher a denominação:

Quando ele denomina Teatro o seu lugar de representação, Burbage escolhe uma referência erudita e humanista, expressando assim o desejo de emprestar 'títulos de nobreza' ao seu trabalho, à sua companhia, aos seus autores e ao seu público; também na Inglaterra a Antiguidade greco-romana atuava como referência. ${ }^{5}$ (SURGERS, 2005b, p. 96, tradução nossa)

Alois M. Nagler (1952, p. VII, tradução nossa) acentua aspectos importantes para a abordagem aqui aplicada: "[...] Shakespeare era não apenas um poeta ou dramaturgo, ele era também ator e produtor. Ele montava suas próprias peças, atuava nelas, e, como acionista, dividia lucros e prejuízos em dois teatros. [...] O estudante

\footnotetext{
4 “En effet, em 1572, une ordennance du Parlement, l'Act for the punishment of Vagabonds, exigeait que chaque troupe de comédiens fût sous la protection d'un noble ou de dignitaires de la justice. Faute de cette protection, qui valeur l'autorisation leur métier, lês comédiens étaient assimiles à dês vagabonds, et comme tels, passibles de prison, ou même du pilori. Em 1572, James Burbage obtint pour sa compagnie la protection du Comte de Leicester, et, deux ans plus tard, celle de la reine elle même."

5 "Quand il appelle Theatre son lieu de représentation, Burbage choisit une référence erudite et humaniste, exprimant par là un desir de donner 'letters de noblesse' à son métier, à sa troupe, à sés auteurs et à son public; en Anglaterre aussi l'Antiquité greco-romaine servait de référence."
} 
do teatro elisabetano não pode ignorar o palco". ${ }^{6}$ Tal assertiva é significativa para a perspectiva do presente trabalho, considerando-se o interesse pelas rotas transversais de ligação entre a dramaturgia e a cena. Aqui, em especial, aquelas que ligam a poesia dramática de William Shakespeare e o palco elisabetano, buscando a credibilidade necessária em documentação que favoreça a presente abordagem, evitando repousar em conjeturas, ou abstrações que originam obscuridade, incerteza, imprecisão, quando se trata de informações sobre sua vida.

Nagler (1964, p. 1, tradução nossa) acentua a dificuldade para apontar o modo como Shakespeare teria começado suas atividades no teatro:

Não sabemos o que levou Shakespeare ao teatro. [...] A história de que ele se juntou a uma companhia itinerante é pura lenda. [...] A lenda diz que um jovem de Stratford tomava conta dos cavalos dos nobres na parte externa de um teatro ou que ele começou sua carreira como um assistente de um diretor de cena [...]. ${ }^{7}$

Como se pode apreender nas considerações de Nagler, muito do que se lê a respeito da vida de Shakespeare parece se aproximar dos ares de lenda, sem evidências ou registros efetivos. Nagler (1964) aponta como primeiro documento da sua presença na condição de dramaturgo, um trecho do trabalho de Thomas Nashe, Pierce pennilesse, em 1592, que remete ao primeiro Henrique IV de Shakespeare. A peça teria sido encenada no Rose Playhouse, de Philip Henslowe que, inclusive, manteve recibos em seu Diário.

Como Nagler (1964) também aponta, no mesmo ano de 1592, no seu testamento literário, Groats-worth of Witte, bought with a million of repentance, Robert Greene menciona o sucesso de Shakespeare. De acordo com Nagler (1964), em dezembro de 1594, uma conta da Corte aponta Shakespeare, juntamente com William Kempe e Richard Burbage, como membros da companhia e servos do Lord Chamberlain. ${ }^{8}$ Ele completa: "Em fins de 1594, Shakespeare atuou diante da Rainha em Greenwich como membro da Companhia do Lord Chamberlain, que se

6 " "...] Shakespeare was not only a poet or a dramatist, he was also an actor and a producer. He staged his own plays, appeared in them, and, as stockholder, shared in the profit and loss of two theatres. [...] The student of Elizabethan drama cannot ignore the stage."

7 "We do not know what brought Shakespeare to the theatre. [...] the story that he joined a troupe of strolling players is pure legend. [...] Legend says that the young man from Stratford guarded the gentry's horses outside one of the theatre or that he started his career as assistant to a stage manager [...]."

8 Menos um mecenas e mais um protetor no sentido de dar segurança aos atores para o desenvolvimento das suas funções. 
compunha de remanescentes de antigas companhias". ${ }^{9}$ (NAGLER, 1964, p. 3, grifo e tradução nossos) Fontes raras e valiosas, que contribuem para um esboço de rotas confiáveis na construção da estatura histórica de William Shakespeare.

O ambiente teatral por ele encontrado ainda guardava traços da práxis cênica medieval e, na Inglaterra, a tradição dos pageants não havia simplesmente desaparecido (Figura 4). O próprio Shakespeare parece, por um lado, manter laços com o pensamento medieval e, por outro, lançar-se numa aventura mais barroca que renascentista. Segundo Nagler (1964), ao chegar a Londres, Shakespeare deve ter encontrado em funcionamento duas casas de espetáculos, o Curtain Playhouse e o Theatre. Um mercador da cidade de Ulm, Samuel Kiechel, em visita a Londres em 1585, escreveu:

E se representam comédias todos os dias; é particularmente interessante assistir os Homens da Rainha (uma companhia mantida pela Rainha) [...] há algumas casas estranhas com três galerias, uma sobre as outras, de modo que uma grande multidão venha sempre assistir esse tipo de entretenimento. ${ }^{10}$ (KIECHEL apud NAGLER, 1952, p. 4-5, tradução nossa)

Determinadas considerações de Victor Hugo (1802-1885), no seu livro William Shakespeare (1864), encaminham reflexões importantes em torno de Shakespeare. Duas delas aparecem já na primeira parte:

Cada peça de Shakespeare, escrita para as necessidades de sua trupe, era, ao que tudo indica, apreendida e ensaiada às pressas pelos atores, no original mesmo, pois não se perdia tempo fazendo cópias; [...] [Há] pouco ou nenhum registro sobre esses teatros quase ambulantes. [...] isso faz compreender porque se encontra tanta obscuridade sobre as épocas em que Shakespeare escreveu suas peças e porque é difícil determinar as datas com precisão.." (HUGO, 1864, p. 33, tradução nossa)

Se Hugo corrobora a opinião de outros estudiosos, no que se refere à imprecisão dos dados biográficos de Shakespeare, ele dá, por outro lado, um testemu-

9 "At the end of 1594 Shakespeare was playing before the Queen in Greenwich as a member of the Lord Chamberlain's troupe, which has been formed from remnants of older troupes."

10 "And comedies are given every day; it is particularly amusing to look on when the Queen's Men [a troupe under protection of the Queen] play, [...] there are some odd houses with three galleries one on top of other so that a large crowd of people always come to watch this kind of entertainment."

11 "Chaque drame de Shakespeare, composé pour les besoins de sa troupe, était, selon toute apparence, appris et répété à la hâte par les acteurs sur l'original même, qu'on ne prenait pas le temps de copier; [...] Peu ou point de registres dans ces théâtres presque forains; [...] ceci fait comprende pourquoi il est resté tant d'obscurité sur les epoques où Shakespeare composa ses drames, et pourquoi il est difficile d'en fixer les dates avec precision." 
nho relevante sobre a qualidade da sua poesia dramática, quando acentua a sua relação com as necessidades da companhia que iria encená-la. Destaca-se o olhar de Shakespeare, voltado para o espetáculo e, inevitavelmente, para as convenções visuais do teatro, do teatro que ele fazia. Tal olhar ficava evidente, não apenas na cena que ele oferecia ao seu público, mas sobreviveu no texto em si. Não se pode escrever dramaturgia impunemente. Ela é uma poesia fértil, repleta de sementes; como um vulcão, pode estar prestes a entrar em erupção. Quem a faz, se efetivamente escreve para a cena, envolve-se ou, melhor, mergulha no seu universo visual.

Mesmo que não registre racionalmente a cumplicidade e, em momentos decisivos, a luz subverta o logos e tome rédeas. Para considerar em Shakespeare a inconfidência imposta ao poeta, pela luz, volto ainda às palavras de Victor Hugo (1864, p. 109-110, tradução nossa):

Homero, Jó, Isaías, Ezequiel, Lucrécio, Juvenal, São João, São Paulo, Tácito, Dante, Rabelais, Cervantes, Shakespeare. | Essa é avenida dos gigantes imóveis do espírito humano. | [...] Cada um deles representa toda a soma do absoluto que o ser humano pode realizar. | [...] Talvez, a extremo rigor, e ainda todas as reclamações seriam legítimas, pudéssemos | designar como os mais altos cimos entre esses, Homero, Ésquilo, Jó, Isaías, Dante e Shakespeare. | Entenda-se que falamos aqui do ponto de vista da Arte, e, na Arte, do ponto de vista literário. | Dois homens nesse grupo, Ésquilo e Shakespeare, representam especialmente o drama. ${ }^{12}$

Tratando particularmente de Ésquilo, Hugo (1864, p. 65, tradução nossa) diz:

[...] Uma espécie de terror preenche Ésquilo, de uma extremidade à outra. Uma profunda medusa move-se vagamente atrás das figuras que se movem na luz. [...]

Ésquilo é o mistério antigo feito homem; algo como um profeta pagão. Sua obra, se a tivéssemos toda, seria uma espécie de Bíblia grega. ${ }^{13}$

\footnotetext{
12 “Homère, Job, Eschyle, Isaïe, Ézéchiel, Lucrèce, Juvénal, saint Jean, saint Paul, Tacite, | Dante, Rabelais, Cervantes, Shakespeare. | [...] Ceci est l'avenue des immobiles géants de l'esprit humain. [...] | Chacun d'eux représente toute la somme d'absolu réalisable à l'homme. | [...] Peut-être à l'extrême rigueur, et encore | toutes les réclamations seraient légitimes, pour | rait-on désigner comme les plus hautes cimes | parmi ces cimes Homère, Eschyle, Job, Isaïe, Dante et Shakespeare. | II est entendu que nous ne parlons ici qu'au point de vue de l'Art, et, dans l'Art, au point de vue litteraire. Deux hommes dans ce groupe, Eschyle | et Shakespeare, representent spécialement le drame."

13 “Une sorte d'épouvante emplit Eschyle d'un bout a l'autre; une méduse profonde s'y dessine vaguement derrière les figures qui se meuvent dans la lumiere. [...] Eschyle est le mystère antique fait homme; quelque chose comme un prophete paien. Son oeuvre, si nons l'avions toute, serait une sorte de Bible grecque."
} 
Deve ser acentuada a contundência da luz na narrativa de Jó, assim como a presença definitiva do fogo em Prometeu acorrentado, de Ésquilo, apesar das alegações de autoria duvidosa. Para introduzir Shakespeare, Hugo (1864, p. 105, tradução nossa) continua: "[...] Shakespeare, é o quê? Poderíamos quase responder: é a Terra"14 Ele ainda afirma que se deve um lugar de destaque para Ésquilo, tecendo muitas relações entre ambos, sublinhando sempre o drama como o núcleo de tais relações: "A epopeia só pode ser grande, o drama é forçado a ser imenso. Essa imensidão é todo Ésquilo e todo Shakespeare". 15 (HUGO, 1864, p. 166, tradução nossa)

Sem a moldura emocional, Jaeger (1995, p. 291-292) afirma:

Infelizmente não temos qualquer ideia precisa das mais antigas formas da tragédia, e, portanto, só podemos julgar as formas superiores da sua evolução. Na forma acabada que vemos em Ésquilo, aparece como o renascimento do mito na nova concepção do mundo e do homem ático a partir de Sólon, cujos problemas morais e religiosos atingem em Ésquilo o seu mais alto grau de desenvolvimento.

Voltando para Hugo, a admiração devotada pelo autor francês àqueles que ele relaciona como gênios, e o destaque para a relação entre Ésquilo e Shakespeare fornecem apoio para o trabalho em andamento, alcançando uma assertiva fundamental: "Shakespeare, o Antigo, é Ésquilo". ${ }^{16}$ (HUGO, 1864, p. 163, tradução nossa) Uma semelhança, em particular, une efetivamente os dois artistas: o modo como trabalhavam para o teatro. Ou melhor, a familiaridade que detinham com a cena do seu próprio tempo; ambos escreviam com o olhar voltado ou impregnado pela práxis cênica.

Sobre a vida de Shakespeare, é possível encontrar inúmeras especulações. Além dos documentos que o localizam na segunda metade do século XVI, membro da Companhia do Lord Chamberlain, sobreviveu até nossos dias aquilo que pode ser um registro muito próximo da sua poesia trágica, o Primeiro Fólio. É um conjunto de trinta e seis das suas obras, publicado em 1623 por William Jaggard, juntamente com seu filho Isaac, e Ed Blount. A contribuição de dois companheiros de Shakespeare, atores da Companhia John Hemminge e Henry Condell, juntando as peças, foi decisiva.

\footnotetext{
14 "Shakespeare, qu'est-ce? On pourrait presque répondre: c'est la Terre."

15 “L’epopée peut n'être que grande, le drame est forcé d'être immense. | Cette immensité, c'est tout Eschyle et c'est tout Shakespeare."

16 Do original: "Shakespeare l'Ancien, c'est Eschyle".
} 
Desafortunadamente, nenhum manuscrito original foi encontrado. Considerando-se que os Foul Papers, ${ }^{17}$ e até os Prompt Books, ${ }^{18}$ poderiam conter indicações e anotações relativas à cena em si, é uma gigantesca lacuna. Hemminge e Condell usaram provavelmente cópias das peças para a organização do Primeiro Fólio, tendo Ralph Crane como escriba na versão que foi impressa. O manuscrito cuidadosamente redigido é até considerado de maior credibilidade, uma vez que os Quartos apresentam, por vezes, certas diferenças em relação ao Primeiro Fólio, o que leva à interpretação de revisão - incluindo cortes - não necessariamente feita pelo autor. Tantas incertezas, que incluem ausência de informações sobre sua vida escolar, deram lugar a longas e acirradas discussões.

A educação formal de William Shakespeare pode ter incluído a leitura de autores da Antiguidade, como Plauto, Ovídio, Horácio, Sêneca; ele pode ter participado de espetáculos comemorativos na escola. Ler latim, traduzir latim-inglês e vice-versa pode ter sido atividade escolar obrigatória. Teria Shakespeare lido Ésquilo? Agamêmnon era uma tragédia que a ele interessava especialmente? Tais indagações contribuem para a abordagem em curso e qualquer que seja a resposta há algo que pode ser mais importante do que autores ou peças: a manifestação teatral em si. ${ }^{19}$ De todo modo, de acordo com Hugo, lendo ou não Ésquilo

17 Os dramaturgos elisabetanos forneciam aos atores manuscritos/fragmentos dos textos, conhecidos como foul papers.

18 Principal cópia de uma peça - e hoje do roteiro de um filme - contendo todas as deixas, movimentos dos atores, assim como da técnica. No teatro norte-americano, fica sob a responsabilidade do Stage-Manager, profissional responsável pelo controle da performance, com formação específica possível, no nível superior. (Pode-se dizer que, no Brasil, há certa correspondência no Diretor de Cena, ainda que este seja confundido com o contrarregra, profissional com outra função, muito importante e supervisionada pelo stage-manager). Também denominado o "livro", Prompt Copy ou Prompt Script. O Stage-Manager, ou o membro da sua equipe responsável por orientar o espetáculo, deve estar muito familiarizado, deve conhecer, deve dominar o Prompt Book e, consequentemente, o espetáculo. Ele deve estar "On the Book". Este documento contém informações detalhadas sobre a casa de espetáculos - ou qualquer que seja o lugar escolhido para a performance -, relatórios dos espetáculos realizados, procedimentos de segurança, emergência, assim como toda informação necessária para a realização de cada performance. É conhecido como a "bíblia" da montagem. Há termos relacionados e conhecidos no Brasil como "ponto", no teatro - artifício usado para dar suporte de texto ao ator em cena, e telepronto, na televisão - expressão provavelmente originada no inglês tele-prompter, dispositivo acoplado ao sistema de vídeo através do qual se fornece (em tempo real) o texto de um programa, ao profissional diante das câmeras. Além do ponto eletrônico, um dispositivo auricular sem fio, que fornece informações ao profissional em cena, ao apresentador de um programa, um repórter, e assim por diante.

19 A familiaridade com o idioma grego na Inglaterra, àquele período, não era comum. A rainha Jane Grey (1536/1537-1554), casada com Lord John Guilford Dudley (1536-1554), reinou por apenas nove dias e nunca coroada, é citada como uma jovem de formação muito abrangente, provavelmente falava grego e pode ser considerada uma exceção: ela devia contar no seu castelo com um daqueles raros especialistas com quem aprendeu este idioma. Lady Jane Grey foi levada ao trono pelo desejo do jovem rei morto Edward VI, que assim determinou em seu testamento, desconsiderando suas irmãs Mary e Elizabeth, na linha sucessória. Lady Jane foi executada na Torre de Londres, sob ordens de Mary I, em 12 de fevereiro de 1554. No mesmo dia, o seu marido foi também executado. 
e, em particular, Agamêmnon, a obra de Shakespeare aponta semelhanças entre ambos, que se referem ao teatro que eles faziam, como o próprio Hugo (1864, p. 168, tradução nossa) descreve: "Atenas, ao sentir que vinha Ésquilo, Sófocles e Eurípedes, deu-se os teatros de pedra. Sem teto, o céu por cobertura, a luz do dia como iluminação." ${ }^{20}$

A interpretação de Hugo (1864) sublinha traços que aproximam os dois poetas e indica a semelhança da práxis na qual sua dramaturgia deveria operar, como estado pré-cênico, uma dramaturgia projetada para completar-se numa tipologia espacial que incluía a exposição à luz do sol, confiando à poesia funções importantes na criação dos lugares e atmosferas.

\title{
A INSTALAÇÃO DE HAMLET ATRAVÉS DA VISUALIDADE
}

A provocação originada na assertiva acima leva a um fragmento da peça The tragedy of Hamlet, prince of Denmarke (Hamlet), ora usando o Primeiro Fólio (Figura 5), ora citando versões modernas, que incluem outras fontes na sua composição, como os Quartos. Dada a inexistência de datas específicas para cada peça, na publicação mencionada, há especulações na tentativa de localizá-las cronologicamente. De qualquer modo, a abertura da obra demonstra a relação de Shakespeare com a cena para a qual ele escrevia:

\author{
ATO I CENA I \\ (Elsinore. Uma plataforma do castelo. Francisco \\ em seu posto. Entra Bernardo) \\ Bernardo Quem está lá? \\ Francisco Responde tu: pra trás e diz quem és! \\ Bernardo Viva o Rei! \\ Francisco É Bernardo? \\ Bernardo É ele mesmo. \\ Francisco Chegaste exatamente em tua hora. \\ Bernardo Acaba de soar a meia noite. \\ Vai tu pra cama; vai dormir, Francisco. \\ Francisco Muito obrigado porque assim me rendes.
}

20 "Athènes, sentant venir Eschyle, Sophocle et Euripide, s'est donné des théâtres de pierre. Pas de toit, le ciel pour plafond, le jour pour éclairage." 
'Stá frio e o coração trago oprimido

Bernardo Foi calma a guarda?

Francisco Não se ouviu um rato.

Bernardo Muito bem. Boa noite. Se encontrares

o Horácio e o Marcelo, companheiros

Desta noite, eu te peço que os apresse.

(Entram Horácio e Marcelo).

(SHAKESPEARE, 1995, p. 29)

Quaisquer que sejam as interpretações, qualquer que seja o teórico eleito para orientar a compreensão da obra, Shakespeare fez muito bem a sua parte. A rubrica de abertura exige um compromisso, no espetáculo; caso alguém se pergunte: para onde entram Bernardo e Francisco? Shakespeare responde com o seu texto: não interessa, agora. Um leitor, que pode ser o diretor, pergunta-se ainda: entram, sim; mas, de onde vêm? De acordo com a primeira fala de Bernardo, ele parece encontrar dificuldade para identificar Francisco. O que pode indicar uma grande distância entre eles.

Por outro lado, a distância relativiza-se com a resposta de Francisco. Ele recusa-se a responder e exige que o outro se identifique. A saudação ao Rei, proferida por Bernardo e sua provável aproximação, deixa pistas para que Francisco o reconheça, a começar pela voz. Bernardo confirma e agora já está próximo o suficiente para que o outro registre: "Chegas exatamente em tua hora". ${ }^{21}$ Bernardo, então, traz uma informação decisiva: são doze horas, hora de ir para a cama. Shakespeare continua construindo atmosfera sem revelar, contudo, o ambiente. Para alguém que tem a função de Sentinela, ir para a cama às doze horas não significa necessariamente que seja noite. Pode ser meio-dia. De qualquer modo, Francisco teve um turno muito tranquilo, apesar do frio que dói no coração, resultante de uma temperatura muito baixa. Bernardo despede-se do companheiro que está deixando o posto, desejando boa noite.

Fica esclarecido, é noite; meia-noite. E não de uma noite qualquer, mas muito fria e escura. Provavelmente com neblina, considerando a dificuldade para se enxergar, mesmo a curta distância, como se pode observar na entrada de Horácio e Marcelo, que se segue: Francisco pensa que pode ouvi-los chegando, mesmo que não possa vê-los perfeitamente. Shakespeare precisou de apenas um minuto para abrir as portas da tragédia, delineando a atmosfera que considera indicada

21 "You come most carefully upon your hour." 
para guiar o espectador por um caminho repleto de atalhos e encruzilhadas. Mas ainda sem revelar o ambiente. Para ele, a atmosfera pode se instalar em muitos ambientes; por isso, ela é mais importante, deve ser construída antes mesmo que se defina um lugar para a ação.

Há, contudo, certas particularidades: versões publicadas após o First Folio informam que Francisco está no seu posto e só depois Bernardo aparece. Levando-se em conta a lógica de uma ação dramática com pressupostos realistas, isso parece plausível. O que Shakespeare tinha em mente, então, quando diz que entram sentinelas, Bernardo e Francisco? A pulsação do seu palco, do seu teatro.

Pode ser diferente num espetáculo moderno, onde se aplicam diversificados instrumentos de corte ou transição realidade-ficção, como luz ou cortina, entre outros. Ele, no entanto, tinha uma cena aberta, e mais, à luz do dia, numa tipologia espacial do teatro que recebeu, em inglês, uma expressão moderna sugestiva: thrust-stage. ${ }^{22} \mathrm{O}$ ator, responsável por Francisco, estaria já em cena desde a entrada do público, aguardando que o outro surgisse, encaminhando a ação? Parece pouco provável. Shakespeare não diz que eles entram simultaneamente, isso é verdade. Pode-se, entretanto, imaginar tudo pronto para começar o espetáculo, entram Bernardo e Francisco, por lados opostos, extremos. Bernardo aproxima-se. Francisco, alerta, percebe o movimento sem identificar visualmente; pode ser qualquer pessoa ou coisa. A ação propriamente dita pode ser iniciada já na atitude de Francisco, que revela o frio, e logo saberemos por que: durante grande parte da cena a atmosfera escura, fria e densa torna-se progressivamente presente, palpável.

O autor encarrega-se de guiar o público apresentando-o à curiosidade incrédula de Horácio, ao introduzir o motivo da sua presença no posto da Sentinela, àquela adiantada hora. Um evento particular vem acontecendo e despertou a atenção dos dois jovens - ele está acompanhado de Marcelo - já que Bernardo é o responsável por assumir o posto, após a saída de Francisco. Logo, precisamente ao soar o sino que anuncia a primeira hora do dia que se inicia - como já acontecera na última madrugada -, surge um espectro. Até o incrédulo Horácio confessa seu pavor e espanto, concordando que o fantasma se assemelha muito ao rei morto, no seu paramento de guerra.

22 "O verbo to thrust, avançar, é aqui revelador. Uma vez que o palco avança em direção ao observador, deslocando-o para as laterais e oferece novos campos visuais, expondo duas outras faces [ou ângulos] da cena. Agora o espectador não somente tem acesso visual à frente do palco, mas ingressa com o seu complexo perceptivo nas faces direita e esquerda, também." 
A curiosidade de Horácio lhe fornece uma espécie de antídoto para seu próprio medo, permitindo-o realizar a bravata de ordenar ao espectro que fale. As especulações parecem indicar que a aparição é um aviso sobre eventos que ameaçam desnudar a aparente tranquilidade. Sua oscilação entre a descrença e o temor revela nuanças da sua personalidade. Bernardo parece convencido de que as aparições fantasmagóricas se relacionam com a notícia da tentativa de retaliação do jovem nobre norueguês Fortimbrás - cujo pai desafiou o rei Hamlet e por ele foi morto em combate - quando o fantasma reaparece, como que lançando dúvidas, alertando para algum outro evento. Diante do seu silêncio, a situação se agrava e alcança o limite do bom senso, quando Marcelo pergunta: "Devo tocá-lo a golpes de alabarda?". ${ }^{23}$ Ainda que a partisan seja uma espécie característica de alabarda de haste longa, continua sendo uma arma branca, que exige certa proximidade do alvo. (Figura 6). E o alvo é um fantasma que, como resposta, desvanece num ponto para imediatamente surgir em outro.

Numa noite fria, na qual uma espessa neblina torna difícil enxergar alguém que se encontra a alguns metros, o espectro parece tornar-se visível - como se tivesse uma luz própria, especial! Tudo isso ocorrendo na área de atuação propriamente dita, num tempo efetivo aproximado de 10 a 12 minutos, numa ação dramática que, contudo, sugere horas; e, segundo Bernardo: "Ia falar, quando cantou o galo". ${ }^{24}$ O canto do galo já anuncia o amanhecer e, no minuto que se segue, Horácio chama a atenção:

Mas olha, a aurora, com seu manto róseo,

Já pisa o orvalho nos distantes montes:

Terminemos a guarda: e, a meu conselho,

Contemos o que vimos esta noite

Ao jovem Hamlet; pois, por minha vida,

Este espírito, mudo para nós, só quer falar com ele. ${ }^{25}$

(SHAKESPEARE, 1995, p. 35)

Shakespeare investe na cumplicidade entre as imagens construídas na sua poesia e o imaginário do espectador, norteado pela experiência humana com a luz. Em pouco mais de 13 minutos, talvez 15, transita-se por uma noite lúgubre,

\footnotetext{
23 "Shall I strike it with my Partizan?"

24 "It was about to speake when the Cocke crew."

25 "[...] But looke, the Morne in Russet mantle clad, | Walkes o're the dew of yon high Easterne Hill, | Breake | we our Watch vp, and by my aduice | Let vs impart what we haue seene to night | Vnto yong Hamlet. For vpon my life, | This Spirit dumbe to vs, will speake to him."
} 
densa, fantástica, alcançando uma madrugada repleta de metamorfoses cromáticas, impregnadas de vermelho, com a luz do dia apontando o esclarecimento, a decisão clara. E tudo isso ocorrendo objetivamente, numa tarde do verão ou outono londrino, numa cena aberta e num teatro sem cobertura, com o espetáculo ocorrendo, portanto, sob a luz do sol.

Sem acentuar efetivamente questões relativas à luz, Nagler (1964, p. 34, tradução nossa) afirma: "[...] O palco elisabetano público conhecia trevas apenas por descrição. Os versos do poeta precisavam construir a atmosfera, [...]". A dramaturgia de Shakespeare representa valioso material para o entendimento das parcerias entre a luz e o teatro do seu tempo, numa poesia dramática construída como passo inicial no caminho para a realização teatral, por um artista que, com ambas, mantinha especial familiaridade. Pode parecer um contrassenso sublinhar positivamente a atitude de Nagler, quando ele prioriza os documentos e, por outro lado, acentuar o interesse em discutir a visualidade, uma vez que a escassez de evidência visual, no que se refere aos espetáculos de Shakespeare, é quase absoluta. Até mesmo as imagens, gravuras, pinturas e esculturas, que pretendem retratá-lo são severamente criticadas; desde sua acuidade técnico-estética, incluindo a análise de sua proporção, questionando a credibilidade como documento histórico-social. Não poderia ser diferente, já que se trata de uma personalidade que despertou tanta atenção, sendo visitada pelo tratamento de outro artista, impregnado pela visualidade de seu tempo.

Mesmo considerando textos importantes, como o de Morton Paterson (1961), que estuda o Office of the revels na época da Rainha Elizabeth, abordando diversos aspectos das festas e dos espetáculos elisabetanos, incluindo a luz, assim como o trabalho de Irwin Smith (1956), que busca uma reconstrução moderna minuciosa do Globe da época de Shakespeare, efetivando uma pesquisa rigorosa, há poucos documentos iconográficos sobre o edifício teatral, produzidos à época. Além dos documentos já mencionados, o interessado na pesquisa sobre a luz no teatro da época de Shakespeare encontrará bom material de estudo no trabalho de Robert B. Graves (1999).

Por outro lado, não fosse encontrado - e publicado por K. T. Gaedertz - a cópia de um desenho que objetiva representar o interior do Swam, na Utrecht University Library da menor província dos Países Baixos do mesmo nome, em 1988, os estudos estariam limitados a descrições, inventários e indicações contidas nas peças. (NAGLER, 1964, p. 9) A ilustração original teria sido desenhada por um estudante ou estudioso alemão que visitava Londres, Johannes De Witt, presumidamente, em 1596, e de localização hoje ignorada. O que se conhece, e foi encontrada por 
Gaedertz, é uma cópia que teria sido feita por Arend van Buchel, amigo de De Witt, e originou inúmeras interpretações e discussões (Figura 7).

Sobre a imagem, Chambers (1923, p. 527, tradução nossa) afirma: "[...] o desenho é a base inevitável para qualquer relato abrangente dos principais aspectos estruturais de uma casa de espetáculos [do período em questão]". ${ }^{26}$ Nagler (1964) acredita que o desenho revela a ocorrência de um ensaio, embora questionado por comentadores, que indicam a bandeira hasteada como sinal de espetáculo. A bandeira pode indicar que haveria sessão naquele dia, mesmo estando o elenco ensaiando no momento da visita. Cada um dos elementos físicos das instalações que aparecem no desenho foi revolvido por debates importantes, desde seu aparecimento, com tentativas de relacionar a poesia dramática de Shakespeare e aquela orientação espacial.

Além de uma tendência a reconhecer o seu valor como documento único, a discussão aponta, também, dúvidas em torno da habilidade de quem executou o desenho e, portanto, sua validade como documento daquilo que De Witt pretendia mostrar. Podem ainda ser consideradas certas convenções - como a superposição de informações no mesmo desenho - e até uma relação direta com a arquitetura teatral romana; os textos em latim, identificando as partes do teatro [orchestra (espaço da plateia reservado para convidados especiais), sedilia (assentos), porticus (galeria coberta)], apontam em tal direção, representando interesse particular de De Witt e van Buchel, ambos envolvidos com a atividade de antiquário. Uma informação parece não sugerir controvérsias: os espetáculos ocorriam durante o dia, sob a luz do sol, uma vez que parte da plateia era descoberta, como mostra o desenho.

Menciona-se ainda outra imagem, uma gravura de Claes Jan Visscher, elaborada por volta de 20 anos depois da viagem de De Witt, mostrando uma vista panorâmica de Londres, provavelmente de 1616. De acordo com Bryson (2009, p. 97, tradução nossa), a confiabilidade da gravura pode ser questionada:

[...] Em 1948 um estudioso chamado I. A. Shapiro demonstrou de maneira bastante conclusiva que Visscher havia baseado seu desenho numa gravura já existente, de 1572, antes que qualquer teatro por ele retratado fosse efetivamente construído. Na verdade, parece que Visscher nunca esteve em Londres não sendo, portanto, a mais confiável das testemunhas. ${ }^{27}$

26 "[...] the drawing is the inevitable basis of any comprehensive account of the main structural features of a [Elizabethan] playhouse."

27 "[...] in 1948 a scholar named I. A. Shapiro showed pretty conclusively that Visscher had based his drawing on an earlier engraving, from 1572, before any of the theatres he depicted had actually been built. In fact it appears that Visscher had never actually been to London, and so was hardly the most reliable of witnesses." 
Bryson (2009) cita também uma gravura de Wenceslas Hollar, executada entre finais da década de 1630 e início da seguinte, na qual se vê uma construção identificada como Bere baiting. Muitos acreditam tratar-se do Teatro Globo. Outras interpretações conjecturam que a mencionada edificação acomodava lutas entre animais, incluindo ursos, de grande apelo, especialmente no que se refere a sua força e agressividade.

Do ponto de vista do espetáculo em si, outras abordagens têm envolvido historiadores e/ou críticos. Nagler apresenta considerações acerca da natureza dos cenários, ponderando que as especulações em torno das decisões dos dramaturgos elisabetanos que, segundo comentadores, tendiam a substituir os aspectos ilusionistas da cenografia por descrições mais ou menos poéticas no texto, não passam de mitos. Contradizendo aqueles que fundamentam tal crença nas intervenções do Coro, em Henry V, ele aponta como principal fonte para sua argumentação o inventário executado pelo proprietário do Rose Playhouse, Philip Henslowe, em 10 de março de 1598. (NAGLER, 1964) Nagler (1964, p. 35, grifo e tradução nossos) acentua: "O teatro elisabetano - nesse caso, o Rose Playhouse em 1598 - não era, de modo algum, um deserto; pelo contrário, determinadas ações eram definitivamente pontuadas por elementos cênicos que se autossustentavam". ${ }^{28}$ Os itens descritos no inventário e destacados por Nagler (1964) incluem: uma rocha, três túmulos, uma "Boca do Inferno", uma jaula (ou cela), duas escadas, dois campanários, um farol, "a cidade de Roma", um loureiro, uma "árvore de maçãs douradas", dentre outros elementos.

Ele parece considerar tais elementos indicadores do espaço da cena e até estruturas cênicas capazes de suportar ou abrigar um ator, ou atores, como um banco, uma árvore, uma tenda. Considerando-se que tais itens representam parte da convenção daquele teatro, o argumento de Nagler parece plausível. Uma vez que a introdução de um inteiro regimento ou uma floresta em cena seria pouco provável, três soldados ou uma árvore poderiam contribuir para construção do ambiente e das relações exigidas pela cena, na moldura de uma convenção específica. O dramaturgo investe numa tentativa de cumplicidade com o espectador, no intuito de aproximá-lo do seu espetáculo. Anne Surgers (2005b) trata do mesmo tema, observando o teatro elisabetano como uma "retórica do visível". (Já no seu primeiro exemplo, para introduzir tal abordagem, pode ser vislumbrada uma relação com o presente enfoque, ainda que seu objetivo seja diferenciado:

28 "The Elizabethan Stage - in this case, the Rose Playhouse in the year 1598 - was by no means a desert, rather that certain actions were definitely pin-pointed by mean of free-standing scenic elements." 
Para ajudar a entender a natureza dessa correlação elisabetana entre o dito e o mostrado, analisarei em primeiro lugar dois exemplos escolhidos na obra de Shakespeare, que tratam o céu. Em O Mercador de Veneza, Lorenzo diz a Jessica: Olha, o piso do céu está todo incrustado com brilhantes discos de ouro (O Mercador de Veneza, a V-1, v. 58-59) [...] A mesma imagem é encontrada na confidência de Hamlet a Rosencrantz e Guildenstern: [...] Vede! O firmamento, esse dossel esplêndido, este teto majestoso trastejado com chamas de ouro (Hamlet, II-2 V. 311 e sSq.). ${ }^{29}$ (SURGERS, 2005b, p. 110, tradução nossa)

Tanto a última imagem, parte da confidência de Hamlet a Rosencrantz e Guildenstern, quanto a fala anterior, de Lorenzo, ambas tratam inequivocamente da luz. A correlação apontada pela autora refere-se a um estado da natureza que, para Shakespeare, como realizador, era imprescindível e só possível na poesia. Mais que uma descrição do lugar ou de eventos, ele mergulha a ação dramática numa atmosfera de nobreza, sob um céu imaginário que resplandece em ouro.

Para concluir o capítulo no qual discute a questão, Surgers (2005b, p. 113, tradução nossa) afirma:

[...] para o teatro elisabetano, a imagem não é da ordem do visível, mas do imaginário. É uma imagem mental, interior, espiritual, que o expectador constrói tanto através do texto falado, respirado e encarnado, quanto através da arquitetura e da cenografia. ${ }^{30}$

Na versão do Primeiro Fólio, em Henry VI, part one, encontra-se: "Entra Purcel na parte superior, empunhando uma tocha acesa". ${ }^{11}$ (SHAKESPEARE, 1623, p. 107, tradução nossa) A prática de usar tal artefato em cena poderia, como se observa nessas didascálias, até indicar escuridão ou noite, num espaço teatral que recebia luz do sol, configurando um traço muito particular para a cena. Parece óbvio que não se trata de uma discussão esgotada e que outros autores podem encontrar

\footnotetext{
29 "Pour aider a comprendre de quelle nature est cette corrélation elisabethaine entre le dit et le montrer, j'analysareait em premier lieu deux examples choisis dans Shakespeare, a propôs du ciel. | Dans Le Marchant de Venise, Lorenzo dit à Jessica: | Regard, le parquet du ciel est tout incrusté de disques d'or étincelants (Le Marchant de Venise, V-1, v. 58-59) [...] | On retrouve La même image dans la confidence de Hamlet à Rosencrantz e Guildenstern:[...] voyer! Le firmament, ce dais splendide, ce toit majesteux fretté de flammes d'ór" (Hamlet, II-2 v. 311 e ssq.).

30 “[...] pour le théâtre élisabéthain, l'image n'est pas de l'ordre du visible mais de l'imaginaire. C'est une image mentale, interieure, spirituelle, que le spectateur se construit tant par l'intermédiaire du text proféré, respiré et incarné que par l'intermédiaire de l'architecure et de la scenographie."

31 "Enter Purcel on the top, thrusting out a Torch burning."
} 
novas justificativas para os textos que, em Shakespeare, descrevem ou sugerem os ambientes; não apenas as incontáveis interpretações, que não cessam de surgir, mas também a possibilidade da descoberta de alguma fonte legítima que fundamente novas abordagens.

Por outro lado, deve-se registrar outra importante relação entre o teatro de Shakespeare e a luz artificial, sua passagem pelo Blackfriars. Tratava-se de um antigo monastério dominicano que foi usado como teatro privado, inicialmente por Richard Farrant, abrigando em princípio o coro de rapazes da Windsor Chapel e, eventualmente, apresentando espetáculos para entretenimento da rainha, a partir de 1576. Vinte anos mais tarde, James Burbage comprou o antigo refeitório do monastério e fez alterações que parecem ter resultado em muita dificuldade e alto custo. Em seguida, Burbage cedeu o espaço para uma companhia de crianças, dirigida por Nathanael Giles e Henry Evans. Um registro no diário de Friedrich Gerschow, viajante alemão que assistiu um dos espetáculos da companhia, diz: "[...] Esses rapazes têm seus instrutores especiais em todas as artes, [...] de modo que eles podem aprender boas maneiras da corte, e são obrigados a apresentar uma comédia toda semana [...] tudo isso com luz [artificial] muito impressionante". (NAGLER, 1964, p. 94, tradução nossa)

Em 1608, de novembro a março de 1609, a companhia King's Men, de Burbage - da qual Shakespeare era integrante, ocupou o Blackfriars, em lugar dos jovens comediantes de Evans. Algumas dentre as últimas peças de Shakespeare teriam sido escritas para o Blackfriars. Desafortunadamente, não há qualquer registro de procedimentos específicos para a incorporação da luz artificial à cena shakespeariana. Pode-se argumentar que a solidificação da sua prática teatral, realizada a céu aberto, o tenha levado a desconsiderar a possibilidade de incorporação da luz, como um movimento estético, que produzisse resultados particulares em sua dramaturgia. Levando-se em conta o que diz Nagler, ao mencionar Gerald Eades Bentley (1901-1994), The Tempest está entre as peças certamente escritas para serem originalmente montadas no Blackfriars.

É difícil, contudo, discutir com segurança a relação do espetáculo com a luz artificial, devido à inexistência de qualquer documentação, como já se ponderou, exceto o próprio texto. Além da peça citada, também Cymbeline e The Winter's Tale, como textos do último período da obra de Shakespeare, teriam sido escritos para serem montados no Blackfriars. A ausência de fontes - como os prompt books, que seriam valiosíssimos - deixa enorme dificuldade para os interessados na visualidade. É inevitável lembrar que a Inglaterra passava por um grave momento polí- 
tico, com a sucessão da Rainha Elizabeth e a ascensão de James I ao trono. Gary Schmidgall (1981) comenta a tendência literária que se afigura na transição de poder, acentuando a necessidade de atenção para o movimento:

Se tivéssemos que entender o dilema que Shakespeare encarou à medida que o estilo teatral jacobino mudava: em poucos anos, ele teve que decidir se aplicava seu talento ao [teatro] público ou ao [teatro] da corte - ou através de alguma alquimia dramática, em ambos. ${ }^{32}$ (SCHMIDGALL, 1981, p. 27, tradução nossa)

\section{SHAKESPEARE À LUZ DA TEMPESTADE}

Outro momento na obra de Shakespeare de grande relevância para a presente abordagem é sua peça, já citada, A tempestade (The tempest). A rubrica de abertura dessa obra, no Primeiro Fólio, alarga a fundamentação para a presente argumentação: "Ato I, Cena I |A bordo de um navio no mar: ouve-se ruído de tempestade, | trovões e raios. | (Entram um Mestre e um Contra-Mestre)". (SHAKESPEARE, 1999, p. 13) Ao ruído que traz a atenção da plateia, logo se junta o desenrolar da ação, provocando o imaginário na direção de imagens da tempestade. Uma múltipla tempestade que se relaciona com a experiência de cada um e a disponibilidade de atuar como cúmplice, criando sua própria visualidade da tormenta. Mais uma vez, como em Hamlet, entram duas personagens. Ao dirigir-se ao segundo, o Capitão lançará a primeira pincelada no quadro imaginário, como num cinema mental:

MESTRE. Contra-mestre!

CONTRAMESTRE. Olá, Mestre: tudo em ordem?

MESTRE. Tudo. Diga aos marinheiros que se não trabalharem rápido, encalhamos: mexam-se, mexam-se!

(SHAKESPEARE, 1999, p. 13)

E, adiante, o Contramestre menciona pela primeira vez a tormenta ou tempestade [storme]. Shakespeare investe decisivamente nas imagens sonoras, quando relaciona a impaciência do mar e os rugidos da natureza, na fala do Contramestre, linha 24 .

32 "If we are to are to understand the dilemma Shakespeare faced as Jacobean theatrical fashion diverged: in a few years he would have to decide whether to employ his talent in public or in private, courtly service - or by some special dramatic alchemy, in both." 
GONZALO. Não, meu amigo; tenha paciência.

CONTRAMESTRE. Quando o mar tiver. Fora! O que é um rei para essas ondas? Pros camarotes! Silêncio! Não nos atrapalhem.

GONZALO. Muito bem; mas lembrem-se de quem têm a bordo. CONTRAMESTRE. Ninguém de quem eu goste mais do que de mim mesmo. O senhor é conselheiro; se puder calar os elementos e trazer paz ao presente, nós não tocamos mais numa só corda; use a sua autoridade. Mas se não puder, dê graças por ainda estar vivo e vá se preparar no camarote para os riscos do que pode acontecer numa hora dessas. Ânimo, meus corações! Já falei, saiam do caminho (Sai). ${ }^{33}$

(SHAKESPEARE, 1999, p. 14)

Observe-se que o termo "ondas" que aparece na tradução ao final da linha 24, originalmente é escrito roa-rers, por Shakespeare, que se refere a rugidos. Note-se que ele aposta nas imagens sonoras, já elaboradas na abertura do espetáculo, enquanto a tradução parece sentir a necessidade da imagem mental do mar. Deve-se registrar que o autor já deu uma reserva para a memória do público, iniciando a ação cênica com ruídos assustadores de tempestade, sugerindo instrumentos para efeitos especiais, de uso provavelmente comum. Shakespeare investe na imagem mental de um mar "impaciente". (SHAKESPEARE, 1999, p. 14) Nem mesmo a presença de um Rei pode acalmar os elementos. A ação da qual as falas tomam parte impele o espectador a se misturar com a atmosfera de ameaça e perigo.

Num momento assim, nem mesmo as mediações do conselheiro de um soberano têm qualquer poder. Mais vale a voz e o comando do Contramestre e a perícia dos marinheiros diante da necessidade de combater os ruidosos elementos. Do espetáculo oferecido pela King's Men no Blackfriars, sob uma luz artificial, cujas características e detalhes técnicos são desconhecidos, restariam apenas especulações sobre o que se conhece da tecnologia daquele momento, levando a imaginar a aplicação de velas (lustres), lamparinas a óleo e tochas; incluindo-se como ingredientes a fumaça e o odor desagradável. A tempestade também é construída na atitude das personagens e consequentes conflitos, interagindo com tais condições.

\footnotetext{
33 "Gonz. Nay, good be patient. | Botes.When the Sea is: hence, what cares these roa-rers | for the name of King? to Cabine; silence: trouble | vs not. | Gon. Good, yet remember whom thou hast aboord. | Botes. None that I more | loue then my selfe. You are | a Counsellor, if you can command these Elements to silence, | and worke the peace of the present, wee will not | hand a rope more, vse your authoritie: If you cannot, | giue thankes you haue liu'd so long, and make your | selfe readie in your Cabine for the mischance of the | houre, if it so hap. Cheerely good hearts: out of our | way I say."
} 
A cena seguinte traz uma revelação contundente: se uma tempestade já representa todas as ameaças e riscos, como a que se presenciou na cena de abertura, fazendo sucumbir uma embarcação, determinando o destino dos seus ocupantes, trata-se de uma tempestade particular, construída deliberadamente pelo Rei Próspero, numa atitude de vingança. É uma tempestade controlada por alguém com poderes especiais e, portanto, repleta dos traços da magia. Shakespeare instala um universo fantástico para a ação, que inclui um homem invisível e danças de espíritos. Aquele que pretenda, portanto, construir tais imagens na cena, tem o privilégio de contar com significativas provocações.

Mencionar a tempestade na obra de Shakespeare aponta, no caso particular da abordagem em curso, para Rei Lear (The tragedy of king Lear). Tratando daquilo que define como o estilo em um projeto de luz para a cena, Linda Essig invoca o mesmo texto, asseverando:

[...] se alguém está projetando Rei Lear, a iluminação não precisa instalar uma tempestade numa charneca com aparência de real. A linguagem de Shakespeare define a realidade de uma tempestade naquele contexto, dando liberdade à luz para criar uma tempestade metafórica, uma tempestade com qualidade teatral, ao invés de buscar a realidade. ${ }^{34}$ (ESSIG, 1997, p. 6, tradução nossa)

Para o designer que atua, hoje, num espaço teatral instalado no interior de uma edificação coberta, com bloqueio para a luz natural e acesso à diversificada e sempre renovada tecnologia, pode ser um desafio construir um projeto, considerando a observação de Essig; tais condições permitem alcançar grande abrangência de resultados, até mesmo a atmosfera realista, mesmo que não seja exatamente uma tarefa fácil criá-la em cena; na contemporaneidade, afinal, o designer pode correr o risco de afogar a ação cênica num volume exacerbado de "efeitos", atendendo ao apelo do senso comum instalado, inclusive, em certos ambientes teatrais.

Em Rei Lear, Shakespeare procura garantir que a atmosfera de uma tempestade particular, como afirma em outros termos Linda Essig, esteja presente - ou seja, construída - no jogo entre o drama e o imaginário do público. Pode-se apreender tal expectativa como uma mixagem de risco, compreensão e confiança nas convenções do teatro de seu tempo. Quantos já testemunharam uma tempestade de tal magnitude e sobreviveram para reativá-la na memória? Shakespeare alia

34 "[...] if one is designing King Lear, the lighting need not necessarily set up a real-looking storm on a heath. Shakespeare's language defines the reality of a storm contextually, freeing the lighting to function to create a metaphorical storm, a storm that functions dramatically rather than realistically." 
às instâncias cognitivas da linguagem, os traços estéticos da sua poesia e do seu teatro, apostando na capacidade perceptiva e imaginativa do ser humano para engendrar uma parceria na construção de atmosferas.

A cena III do Ato 3 é sempre trazida à discussão, já que ali se desenvolve a tempestade enfrentada por Lear. É indispensável, contudo, voltar a momentos anteriores, do Ato 1, onde Shakespeare inicia a construção progressiva da atmosfera que a ele interessa. O desequilíbrio que provocará a ira dos elementos naturais manifestada no Ato 3 começa a ser delineado já na tormenta metafórica, que se instala na mente de algumas personagens, com ênfase em Lear. A incapacidade de julgamento é revelada pelo Rei que aceita o discurso superficial das filhas mais velhas, como em Goneril: "[...] Senhor, pro meu amor faltam palavras; [...]" (SHAKESPEARE, 1998, p. 16), ${ }^{35}$ e em Regan: “[...] Pois minha única felicidade | Reside em vosso amor" (SHAKESPEARE, 1998, p. 17), ${ }^{36}$ desconsidera a franqueza expressa por Cordelia: "Infeliz, não sou capaz de botar | Na boca o coração. A vós eu amo | Nem mais nem menos do que é meu dever". ${ }^{37}$ (SHAKESPEARE, 1998, p. 17-18) Tal incapacidade culminará com reações e sentimentos tempestuosos do soberano. Começando, por deserdar a filha mais jovem, momento no qual shakespeare invoca, de modo contundente, as relações com a natureza:

Que seja! E co'a verdade pra seu dote!

Pois pelo brilho sagrado do sol,

Os mistérios de Hecate e da noite.

Pelo curso dos astros aos quais nós

Devemos o existir e a finitude,

Aqui renego o cuidado paterno,

Todo o poder da consanguinidade,

E como estranha a mim e ao meu amor

A tenho sempre $[\ldots] .^{38}$

(SHAKESPEARE, 1998, p. 18-19)

35 "Sir, I loue you more than word can weild y matter; [...]."

36 "And finde I am alone felicitate In your deere Highnesse loue."

37 "Vnhappie that I am, I cannot heaue | My heart into my mouth: I loue your Maiesty | According to my bond, no more nor lesse."

38 "Let it be so, thy truth then be thy dowre: | For by the sacred radience of the Sunne, | The misteries of Heccat and the night: | By all the operation of the Orbes, | From whom we do exist, and cease to be | Heere I disclaime all my Paternall care, | Propinquity and property of blood, | And as a stranger to my heart and me, | Hold thee from this for euer. [...]." 
Clamando pelo Sol e envolvendo as propriedades misteriosas da noite personificada por Hecate 39 - Lear invoca todo o universo para deserdar e destituir Cordelia da qualidade de filha. Na sua mais grave crise, Lear escala o mais alto dos cumes, em busca da mais poderosa luz, o Sol, e se lança no mais profundo abismo para encontrar as trevas, a noite. Shakespeare confiava em tal relação para expressar a natureza humana. E mais importante: para além do julgamento superficial e ocioso que se recosta na adjetivação de maniqueísta, ele provoca a percepção das incontáveis relações luz-sombra-penumbra, não necessariamente em tal ordenamento. No espaço entre o brilho reluzente de Apollo ${ }^{40}$ e na tenebrosa profundidade de Hecate, estão corporificados os desejos humanos que podem gerar múltiplos acentos, intervalos, espessuras, traços, temas, manchas.

Vale lembrar que a figura de Hecate aparece também em Sonho de uma noite de verão (A midsummer night's dream): "Nós, duendes, que corremos | Com o trio da maldição, | E o que do Sol esquecemos | No sonho da escuridão, | Vamos brincar". ${ }^{41}$ (SHAKESPEARE, 1995, p. 192) A tradução apresentada intenta aproximar o leitor, ao substituir a deusa (como aparece no original) por "maldição", facilitando a apreensão, exigindo menor esforço. Para o iluminador de um espetáculo que aceite o texto como provocação, no entanto, o direito de ignorar a presença de Hecate na escrita original pode ser bastante relativo: ele pode empreender trocas entre traços particulares da dramaturgia e o seu imaginário, considerando a natureza da divindade, abrindo portas para o espetáculo.

A sua presença pode favorecer múltiplas apreensões, uma vez que ela tem o privilégio de diversificados domínios, nos quais se incluem o dom da eloquência nas assembleias, a vitória nas batalhas, a prosperidade material, a abundância, a magia, os encantamentos e o mundo das sombras.

Destaque-se em seguida a fala de Goneril, quando ela relaciona ação cênica e tempo: "Irmã, não é pouco o que tenho a dizer, que afeta a nós | ambas. Creio que nosso pai parte hoje daqui". (SHAKESPEARE, 1998, p. 27) ${ }^{42}$ Por outro lado, o poeta investe também numa cumplicidade com os elementos da natureza, para construir a metafórica atmosfera da tempestade. As relações humanidade-natureza, invocadas por Lear na cena 1 do Ato 1, avolumam-se na cena seguinte, aparecendo

\footnotetext{
39 Hekátē, do grego Eкó $\imath \eta$, divindade da luz e das trevas da magia noturna.

40 Em grego A $\pi$ ó $\lambda \lambda \omega v$ (Apóllōn) ou A $\pi \varepsilon ́ \lambda \lambda \omega v$ (Apellōn). Não somente Deus da Poesia, mas também chamado Phoebus Apollo ou Apolo, o brilho reluzente.

41 " $[. .$.$] And we Fairies, that do runne, | By the triple Hecates teame, | From the presence of the Sunne, | Following$ darkenesse like a dreame, | Now are frollicke."

42 "Sister, it is not little I haue to say, | of what most neerely appertaines to vs both, | I thinke our Father will hence to night."
} 
já na abertura, com Edmund: "Tu, Natureza, és minha deusa”. (SHAKESPEARE, 1998, p. 28) ${ }^{43}$ Adiante, Gloucester - pai de Edmundo - exclama:

Esses recentes eclipses do Sol e da Lua não nos prenunciam nada de bom. Embora o conhecimento da natureza possa dar estas ou aquelas causas racionais, mesmo assim a natureza se vê açoitada pelas consequências: o amo(r) esfria, os amigos brigam, os irmãos se separam. Nas cidades, os motins; nos países, discórdias; nos palácios, traições; e quebradas as ligações entre o filho e o pai. Esse meu vilão se enquadra nessas previsões: é um filho contra o pai; o Rei se afasta do caminho da natureza: é um pai contra a filha. Já vivemos o melhor do nosso tempo [...]. ${ }^{44}$ (SHAKESPEARE, 1998, p. 33)

A natureza lança maus presságios sobre a condição humana e, simultaneamente, é atingida pelos eventos produzidos pela humanidade. Edmund, o filho bastardo de Gloucester, parece discordar de seu pai, ao criticar a atitude de responsabilizar os elementos naturais pelas desventuras e feitos negativos do ser humano, numa postura renascentista, que desconstrói crenças difundidas pelo pensamento medieval:

[...] quando vai mal nossa fortuna - muitas vezes como resultado de nosso próprio comportamento - culpamos pelos nossos desastres o Sol, a Lua e as estrelas, como se fôssemos vilões por necessidade, tolos por compulsão celeste, safados ladrões e traidores por predominância das esferas, bêbados, mentirosos e adúlteros por obediência forçada a influências planetárias. ${ }^{45}$ (SHAKESPEARE, 1998, p. 34)

Ainda que Shakespeare aponte questionamentos para tal crença, o encaminhamento dos fatos, a ação dramática por ele construída revela no pai Lear, traído pelas próprias filhas, uma ira que sugere insanidade - quando menos temporária - como uma manifestação da natureza. Se ao final da tragédia, a conjuntura

43 "Thou Nature, art my Goddesse."

44 "These late Eclipses in the Sun and Moone por- | tend no good to vs: though the wisedome of Nature can | reason it thus, and thus, yet Nature finds it selfe scourg'd | by the sequent effects. Loue cooles, friendship falls off, | Brothers diuide. In Cities, mutinies; in Countries, dis- | cord; in Pallaces, Treason; and the Bond crack'd, 'twixt | Sonne and Father. This villaine of mine comes vnder the | prediction; there's Son against Father, the King fals from | byas of Nature, there's Father against Childe. We haue | seene the best of our time [...]."

45 "[...] when we are sicke in fortune, often the surfets of our own | behauiour, we make guilty of our disasters, the Sun, the | Moone, and Starres, as if we were villaines on necessitie, | Fooles by heauenly compulsion, Knaues, Theeues, and | Treachers by Sphericall predominance. Drunkards, Ly- | ars, and Adulterers by an inforc'd obedience of Planatary | influence." 
política alcança sua mais grave crise, culminando no combate inglês contra forças francesas, o poeta revela momentos contundentes, já no ato três, cena três, nos quais a interação entre o ser humano e os elementos naturais revela a tempestade, invocada na poesia. Mesmo que se possa sublinhar a sequência final, onde se precipitam os eventos decisivos para o conflito - as mortes dos principais envolvidos na ação cênica -, o Ato 3 revela um momento no qual humanidade e natureza se unem numa simbiose que alcança ápice importante na presente abordagem. Para chegar a tal ponto, Shakespeare pontua estrategicamente, como um compositor que desenvolve variações sobre um mesmo tema.

Se a tormenta será materializada pelas intempéries, ela já parece presente na alma das personagens. Acentue-se o agravante das relações entre uma cena exposta à luz natural e o desejo do poeta de descortinar uma tormenta devastadora, na qual os elementos naturais interagem, provocando um desequilíbrio descomunal. Já nos primeiros momentos da cena I do Ato 2, os eventos revelam sentimentos tempestuosos entranhados nas almas, como eco e reflexo da ira instalada no coração do Rei Lear. Shakespeare já introduz, na primeira cena do Ato 2, a construção de um ambiente que abriga as nefastas ações de Edmund, ao acusar seu meio-irmão Edgar de traição a Gloucester, pai de ambos.

E o ambiente é mergulhado na atmosfera noturna: "E o Senhor também! Estive com seu pai e dei-lhe a | notícia de que o Duque de Cornwal e Regan, sua du- | quesa, estarão esta noite aqui com ele". ${ }^{46}$ (SHAKESPEARE, 1998, p. 6o)

Pode-se até argumentar que seria difícil precisar certos intervalos temporais entre uma e outra cena. A atmosfera, contudo, é perseguida de modo quasi-musical. O próprio filho bastardo menciona a noite, em três momentos da primeira parte da ação, na linha 943, além das linhas 952 e 954, no Primeiro Fólio:

$$
\begin{aligned}
& \text { Meu pai vela. Senhor, fuja daqui. } \\
& \text { Um espião já disse onde se esconde; } \\
& \text { A vantagem de agora é ser de noite. } \\
& \text { Acaso andou falando de Cornwall? } \\
& \text { Trazendo Regan. Não andou falando } \\
& \text { A favor dele contra o Duque de Albany? } \\
& \text { Pense bem. }{ }^{47} \text { (SHAKESPEARE, 1998, p. 61) }
\end{aligned}
$$

\footnotetext{
46 "Cur. And your Sir, I haue bin | With your Father, and giuen him notice | That the Duke of Cornwall, and Regan his Duchesse | Will be here with him this night."

47 "My Father watches: O Sir, fly this place, | Intelligence is giuen where you are hid; | You haue now the good aduantage of the night, | Haue you not spoken 'gainst the Duke of Cornewall? | Hee's comming hither, now i'th' night, i'th' haste, | And Regan with him, haue you nothing said."
} 
À noite é associada a qualidade de refúgio, na qual o negativo se afirma, sob a proteção das trevas. Retirando do outro o poder da visão, ele o mergulha na incapacidade perceptiva, na ignorância. Após simular um combate com o irmão, ouvindo o pai que se aproxima acompanhado de servos, Edmund constrói tal qualidade, exclamando:

Estou ouvindo o meu pai vir. Perdão,

Mas tenho de fingir que tiro a espada.

Vamos, defenda-te! Lute direito!

Alto! Entregue-se a meu pai! Socorro! Luzes!

(à parte) Fuja irmão! Alto Tochas! Tochas!

(à parte) Boa viagem! ${ }^{48}$

(SHAKESPEARE, 1998, p. 61-62)

Depois de sugerir ao irmão que fuja protegido pela escuridão, ele usa as trevas para ferir a si mesmo, simulando uma ação fratricida e, exige urgência aos servos, que se aproximam transportando tochas. Que iluminem a trilha da fuga de Edgar! Sua descrição do embate é um movimento eficiente para indicar o ambiente, a atmosfera, assim como traços do seu caráter:

(Entram Gloucester e criados, com tochas.)

Gloucester - Onde está o vilão?

Edmund - Estava aqui no escuro, a espada em punho.

Com invocações do mal, chamava a Lua

Para apoiá-lo.

Gloucester - Mas onde está ele?

Edmund - Veja, eu sangro.

Gloucester - Onde está o vilão, Edmund?

Edmund - fugiu por cá, quando não conseguiu...

Gloucester - Atrás dele! (Saem alguns criados). ${ }^{49}$

(SHAKESPEARE, 1998, p. 62)

48 "I heare my Father comming, pardon me: | In cunning, I must draw my Sword vpon you: | Draw, seeme to defend your selfe, | Now quit you well. | Yeeld, come before my Father, light hoa, here, | Fly Brother, Torches, Torches, so farewell."

49 "Enter Gloster, and Seruants with Torches. | Glo. Now Edmund, where's the villaine? | Bast. Here | stood he in the dark, his sharpe Sword out, | Mumbling of wicked charmes, coniuring the Moone | To stand auspicious Mistris. Glo. But where is he? | Bast. Looke Sir, I bleed. | Glo. Where is the villaine, Edmund? | Bast. Fled this way Sir, when by no meanes he could. | Glo. Pursue him, ho: go after." 
Com a saída dos servos, levando consigo as tochas e mergulhando a ação em profunda penumbra, Edmund, o filho bastardo, concretiza seu plano de transformar Edgar num vilão; ele insinua atos de bruxaria que invocam a lua na escuridão, além de inventar um suposto plano de Edgar para assassinar o próprio pai. O mesmo Edmund, racional e descrente das influências da natureza nas ações humanas, confessa haver usado o poder divino como argumento para dissuadir seu irmão, fazendo-o abandonar a ideia de assassinato do próprio pai:

$$
\begin{aligned}
& \text { Eu lhe disse que os deuses da vingança } \\
& \text { Vibram seus trovões nos parricidas; } \\
& \text { Lembrei-lhe os laços fortes e variados } \\
& \text { Que ligam pai e filho [...]. }{ }^{50} \\
& \text { (SHAKESPEARE, 1998, p. 63) }
\end{aligned}
$$

E Shakespeare conclui, reafirmando a noite no diálogo entre Cornwall, Regan e Gloucester, cena 1, Ato 2: "Cornwall - Não sabe por que viemos visitá-lo... | Regan - Fora de hora, em meio à noite escura [...]".51 (SHAKESPEARE, 1998, p. 66)

Depois da cordial recepção de Gloucester, Cornwall e Regan saem acompanhados do anfitrião. É uma nova ação para a qual o autor estabelece um ataque preciso. A primeira fala de Steward, na cena que se segue, é decisiva para a imagem mental criada em cada um que ocupa a plateia: "Bom dia, amigo. És aqui da casa?". ${ }^{2}$ (SHAKESPEARE, 1998, p. 67) Pode-se dizer que a transição noite-dia é instalada, ainda que ao final do encontro Kent lance a estranha ameaça: "Puxa a espada, calhorda! Pois mesmo | que seja noite, a Lua está brilhando. Vou fazer uma papa | de ti, ao luar, seu filho". ${ }^{33}$ (SHAKESPEARE, 1998, p. 69)

Ainda que a noite persista por alguns momentos, portanto, mesmo sem quaisquer menções a artefatos de luz artificial, Kent - mensageiro de Lear - encarrega-se de esclarecer que é perfeitamente possível atacar seu oponente, já que iluminado pela luz da Lua. Trata-se de um luar observado de modo muito especial, distanciado do lugar-comum romântico. Um luar frio, agressivo, que perpassa a práxis cênica em momentos muito especiais, quando tal qualidade atmosférica é exigida pela ação.

\footnotetext{
50 "But that I told him the reuenging Gods, |'Gainst Paricides did all the thunder bend, | Spoke with how manifold, and strong aBond | The Child was bound to'th' Father."

51 "Cor. You know not why we came to visit you? | Reg. Thus out of season, thredding darke ey'd night."

52 "Good dawning to thee Friend, art of this house?"

53 "Draw you rogue, | for though it be night, yet the Moone shines, Ile make a | sop oth' Moonshine of you [...]."
} 
Essa estratégia atua como um instrumento eficaz aplicado pelo autor para instalar a ação. Kent logo será punido pelas suas atitudes. Os nobres de Cornwall encarregam-se de proferir a sentença: "Cornwall - Tragam o tronco! Pela minha honra | Ficará nele até o meio-dia. | Regan - Meio-dia? Até a noite e a noite toda". ${ }^{54}$ (SHAKESPEARE, 1998, p. 74)

A atmosfera noturna permanece como um abrigo para a cena até o último momento, quando Kent, preso ao artefato de tortura, diz: "[...] Fortuna, boa noite; sorri e gira tua roda!". ${ }^{5}$ (SHAKESPEARE, 1998, p. 76) Por outro lado, o momento seguinte parece prescindir de tempo objetivo: Edgar, transformado no mendigo "lunático" Tom, para escapar da caçada na qual desempenha o papel do animal encurralado, prepara-se para enfrentar as intempéries corporificadas no texto: "[...] Os ventos e perseguições do céu". ${ }^{66}$ (SHAKESPEARE, 1998) Não bastasse o infortúnio de ser considerado traidor pelo próprio pai, ele está ameaçado do castigo imposto pela natureza. E, mais importante do que o tempo objetivo, do que dia e hora, é que sua vida será invadida pelos ventos e pela ira dos céus; o que pode transformar um dia de sol brilhante numa noite sem fundo, como um eclipse. Ainda que o Globo pudesse apresentar um relativo conforto no outono londrino - se comparado ao rigor do inverno - Shakespeare acentuará a atmosfera da ação dramática na qual a dureza fria e afiada dos eventos não parece perto de se extinguir.

A tempestade de ira que habita o Lear traído pelas filhas revela seus traços no caráter de Edmund e também no seu pai Gloucester, que ordena a perseguição do seu filho legítimo. Até alcançar o Ato 3, o espectador terá sua imaginação sucessivamente provocada, aproximando-o da tempestade. Na cena 4 do ato 2 - se o monólogo de Edgar for considerado como cena 3, como em versões modernas - o Bobo reflete: "O inverno ainda não acabou se os gansos selvagens | Voam nessa direção". (SHAKESPEARE, 1998) E na mesma cena aparece pela primeira vez o verbo chover, seguido do vocábulo tempestade (storme), quando o Bobo diz:

\footnotetext{
54 "Corn. Fetch forth the Stocks; | As I haue life and Honour, there shall he sit till Noone. | Reg. Till noone? till night my Lord, and all night too."

55 Do original: “[...] Fortune goodnight, | Smile once more, turne thy wheele”. Preferi, neste caso particular, apresentar outra possibilidade de tradução, para acentuar a imagem da roda da fortuna, já conhecida desde a Idade Média, comum àquela época e incluída pelo próprio Shakespeare em outros textos como As you like It (1.2.30) e Henry V (3.3.27), para dar dois exemplos.

56 "The Windes, and persecutions of the skie."
} 
[...] Quem não serve mas explora,

Ou só serve pra constar,

Quando chove vai-se embora;

Tempestade, nem falar [...]. ${ }^{57}$

(SHAKESPEARE, 1998, p. 81)

Além da chuva e dos ventos que já foram lançados por Shakespeare em momentos anteriores, aparecem também raios, relâmpagos e trovões - como na mencionada fala de Edmund (SHAKESPEARE, 1998, p. 63) -, antecipando a tempestade que se instalará no Ato 3. Lear, por seu turno, depois de ter o seu pedido de abrigo para os seus seguidores negado pelas filhas, vocifera para Goneril:

Eu peço, filha, que não me enlouqueça:

Não hei de importuná-la, filha; adeus,

Separados, não mais nós nos veremos;

Porém és minha carne, sangue, filha,

Ou és doença que eu tenho na carne

E devo dizer minha: uma bolha

Uma chaga de peste, ou um furúnculo

Do meu sangue corrupto. Não, não falo:

Eu não chamo a vergonha que virá,

Eu não invoco quem manda o trovão,

Nem a entrego ao tribunal de Júpiter..$^{58}$

(SHAKESPEARE, 1998, p. 88)

Lear envolve o julgamento de Júpiter, anunciando a reação dos céus. Os termos storme e tempest - voltarão a aparecer apenas na sequência final da cena 4 do segundo ato e, importante, pela primeira vez numa rubrica. O autor não apenas usa o segundo termo, de origem latina, e que se refere a uma atuação violenta dos ventos, mas também inclui o primeiro, cuja raiz germânica indica: "Um violento distúrbio climático com ventos fortes e frequentemente chuva, trovão, raios ou neve". ${ }^{59}$ (OXFORD ADVANCED LEARNER'S DICTIONARY, 2010, tradução nossa)

57 "That Sir, which serues and seekes for gaine, | And followes but for forme; | Will packe, when it begins to raine, | And leaue thee in the storme, [...]."

58 "I prythee Daughter do not make me mad, | I will not trouble thee my Child; farewell: | Wee'l no more meete, no more see one another. | But yet thou art my flesh, my blood, my Daughter, | Or rather a disease that's in my flesh, | Which I must needs call mine. Thou art a Byle, | A plague sore, or imbossed Carbuncle | In my corrupted blood. But Ile not chide thee, | Let shame come when it will, I do not call it, | I do not bid the Thunder-bearer shoote, | Nor tell tales of thee to high-iudging loue, [...]."

59 Storm 1. very bad weather with strong winds and rain, and often thunder and lightning. 
Tal indicação é crucial para a compreensão da qualidade do texto de Shakespeare, como estágio do processo de elaboração da cena, independente do Promptbook. Considerando a importância do som no teatro elisabetano, pode-se inferir que a tempestade, a tormenta, cai de modo estrondoso sobre o público.

O poeta ataca a questão de frente. A imagem da tempestade se alarga, desde o pensamento de personagens enfurecidas, em particular o Rei, até os elementos da natureza. Toda a ira de Lear leva-o a praguejar desmedidamente:

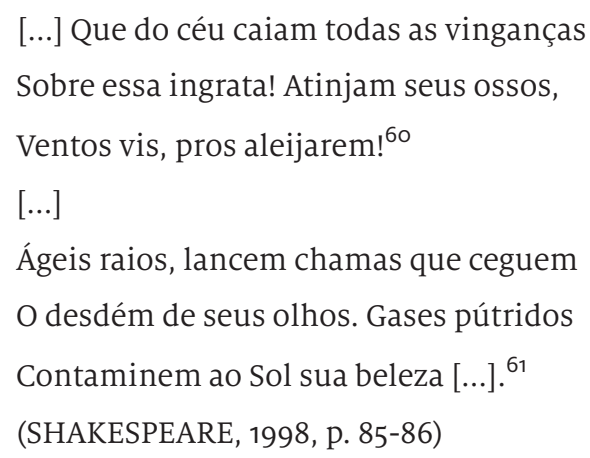

Confirma-se a devastação da tempestade, já na alma do Rei ofendido pelas filhas e, ao contrário do que ele pede, logo os céus cairão sobre sua própria cabeça. Uma primeira vez, Cornwall é o mensageiro que se comunica com o espectador, para apontar a ameaça no horizonte: "Vamos entrar. Vai haver tempestade". ${ }^{62}$ (SHAKESPEARE, 1998, p. 91) Na mesma cena, Gloucester, que havia saído, seguindo Lear, retorna e informa: "O Rei está furioso". ${ }^{3}$ (SHAKESPEARE, 1998, p. 92) E, mais uma vez, agora na sua última intervenção do Ato 2, como um arauto que anuncia, como o coro que antecipa e prepara, como um narrador que introduz, Cornwall lança definitivamente a tempestade sobre o espectador, alertando Gloucester: "Tranque as portas; a noite 'stá violenta. | Regan diz bem: saiamos da tormenta". 64 (SHAKESPEARE, 1998, p. 93)

No Ato 3, fica estabelecido o estado de tormenta que se impõe sobre o ambiente, desde o início da ação. A primeira rubrica do ato define: "Uma charneca. Tempestade, com raios e trovões. Entram Kent e um Cavalheiro, que se

\footnotetext{
60 "All the stor'd Vengeances of Heauen, fall | On her ingratefull top: strike her yong bones | You taking Ayres, with Lamenesse."

61 "You nimble Lightnings, dart your blinding flames | Into her scornfull eyes: Infect her Beauty, | You Fen-suck'd Fogges, drawne by the powrfull Sunne, [...]."

62 "Let vs withdraw, 'twill be a Storme [...]."

63 "The King is in high rage."

64 "Shut vp your doores my Lord, 'tis a wil'd night, | My Regan counsels well: come out oth' storme."
} 
encontram". ${ }^{65}$ (SHAKESPEARE, 1998, p. 94) Tal informação deve chegar ao espectador através de artefatos introduzidos na cena, principalmente efeitos sonoros, contribuindo para a apreensão da violência da tempestade. O diálogo se encarrega de desenvolver a espessura, a dimensão, a profundidade da imagem, já nas duas primeiras falas, dada a importância a ela conferida por Shakespeare. Tal imagem pode levar, ao espectador, a luz que habitou a imaginação do autor, nos momentos de criação da sua poesia:

Kent - Quem está aí, além do mau tempo?

Cavalheiro - Um que se vê inquieto como o tempo.

Kent - Eu o conheço. Aonde está o Rei?

Cavalheiro - Lutando com os inquietos elementos,

Pede ao vento que o mar afogue a terra,

Ou que subam as águas para os montes,

que tudo cesse ou mude. ${ }^{66}$

(SHAKESPEARE, 1998, p. 94)

As linhas citadas a seguir aparecem na continuação da réplica do Cavalheiro - no Primeiro quarto, de 1608, assim como nas versões modernas do Primeiro Fólio e mergulham a ação numa tormenta particular: além do frio, da chuva, dos ventos e trovões. O Cavalheiro tem aí função específica, contribuindo para instalar a tempestade e, além disso, não bastassem os rigores da intempérie, ele amplia a gravidade:

E as lufadas do vento, cego em fúria,

Pegam no ar as cãs que não respeitam.

Quer que o humano derrote a tempestade,

A ventania e a chuva que se batem.

Nesta noite, em que o urso esconde a prole. ${ }^{67}$

(SHAKESPEARE, 1998, p. 94-95)

Shakespeare radicaliza e revela uma terra coberta pelo véu das trevas noturnas e, antes do final da cena, Kent ainda exclama: "Maldita tormenta!" 88

65 "Storme still. Enter Kent, and a Gentleman, seuerally."

66 "Kent. Who's there besides foule weather? | Gen. One minded like the weather, most vnquietly. | Kent. I know you: Where's the King? | Gent. Contending with the fretfull Elements; | Bids the winde blow the Earth |into the Sea, | Or swell the curled Waters 'boue the Maine, | That things might change, or cease."

67 "[...] Which the impetuous blasts with eyles rage | Catch in their furie, and make nothing of, | Striues in his little world of man to outscorne, | The too and fro conflicting wind and raine, | This night wherin the cub-drawne Beare would couch."

68 "Fye on this Storme, [...]." 
(SHAKESPEARE, 1998, p. 96), confirmando-se a manifestação da tempestade, já na primeira rubrica da cena seguinte: "Continua a tempestade". ${ }^{99}$ (SHAKESPEARE, 1998, p. 97) Além de definir a presença da tempestade em seis momentos particulares da didascália - entre as linhas 1614 e 1615, 1655 e 1656, 1780 e 1781, 1843 e 1844, 1880 e 1881, 1942 e 1943 - já no início da cena 2, ela é sublinhada quando Lear esbraveja:

Soprai ventos; rasgai a face em fúria!

Vós, cataratas e tufões jorrai

E afogai campanário e catavento!

Fogos de enxofre, que sois arautos

Dos raios que bifurcam os carvalhos,

Queimai minha cabeça branca. E vós,

Trovão que tudo treme, golpeai

A espessura rotunda deste mundo!

Quebrai a forma e ora espalhai os germes

Da natureza que faz o homem ingrato! ${ }^{70}$

(SHAKESPEARE, 1998, p. 97)

Diante do perigo imposto pela tormenta, o Bobo reconhece e aconselha: "[...] esta noite não tem dó de sábio nem de bobo". ${ }^{71}$ (SHAKESPEARE, 1998, p. 97) E Lear continua:

Ribomba o ventre! Cospe fogo e chuva!

Não tenho filha vento, fogo ou chuva:

Não vos chamo de ingratos, elementos;

Não vos dei reinos nem chamei-vos filhas.

Não me deveis lealdade; jorrai, pois,

Vosso horrível prazer; pois sou vosso escravo,

Um velho pobre, fraco e desprezado. ${ }^{72}$

(SHAKESPEARE, 1998, p. 97)

\footnotetext{
69 D "Storme still."

70 "Blow windes, \& crack your cheeks; Rage, blow | You Cataracts, and Hyrricano's spout, | Till you haue drench'd our Steeples, drown the Cockes. | You Sulph'rous and Thought-executing Fires, | Vaunt-curriors of Oake-cleauing Thunder-bolts, | Sindge my white head. And thou all-shaking Thunder, | Strike flat the thicke Rotundity o'th' world, | Cracke Natures moulds, all germaines spill at once | That makes ingratefull Man."

71 "[...] heere's a night pitties | neither Wisemen, nor Fooles."

72 "Rumble thy belly full: spit Fire, spowt Raine: | Nor Raine, Winde, Thunder, Fire are my Daughters; | I taxe not you, you Elements with vnkindnesse. | I neuer gaue you Kingdome, call'd you Children; | You owe me no subscription. Then let fall | Your horrible pleasure. Heere I stand your Slaue, | A poore, infirme, weake, and dispis'd old man: [...]."
} 
Adiante, Kent apresenta a união da escuridão da noite com a dureza do clima hostil:

[...] Mesmo quem ama a noite,

Não ama as como esta: os céus irados

Assustam os que erram pelo escuro

E os prendem na toca. Em toda a vida,

Lençóis de fogo, roncos de trovão,

Gemidos e vento e chuva como estes

Não me lembro de ouvir; e é mais que o homem

Aguenta em medo e susto. ${ }^{73}$

(SHAKESPEARE, 1998, p. 98-99)

A literatura, e principalmente o cinema, aprendeu em fontes dessa qualidade a possibilidade de unir tais características. São incontáveis os filmes - o que até desgastou tal estratégia, transformando-a em rotina - nos quais a insanidade, a morte, o perigo e o temor são vinculados às trevas, à noite, assim como às tormentas.

Shakespeare insiste em traços da atmosfera no diálogo - com diversas menções específicas à chuva, ao vento, à tempestade, à tormenta e ao trovão, ao longo do Ato 3. Na cena 4, ainda Kent: "A tirania da noite é ruim demais para a natureza arcar. (Continua a tempestade)". (SHAKESPEARE, 1998, p. 110)

O Rei Lear, dada sua relevância para a fábula, sublinha reiteradas vezes a agressividade do clima e da atmosfera, como nos exemplos a seguir:

[...] Em noite assim

Trancar-me fora? À chuva eu resisto,

Em noite assim? [...]. (3.4.1797-1799) $)^{74}$

[...] Não consigo pensar nessa tormenta,

Nas coisas que mais me doem [...]. (3.4.1805-1806) $)^{75}$

[...] Desgraçados sem roupa, onde estiverem,

Enfrentando o açoite da tormenta,

Como podem assim, com flancos magros,

73 "[...] Things that loue night, | Loue not such nights as these: The wrathfull Skies | Gallow the very wanderers of the darke | And make them keepe their Caues: Since I was man, | such sheets of Fire, such bursts of horrid Thunder, | Such groanes of roaring Winde, and Raine, I neuer | Remember to haue heard. Mans Nature cannot carry | Th' affliction, nor the feare."

74 "[...] in such a night, | To shut me out? Poure on, I will endure: | In such a night as this? O Regan, Gonerill, [...]."

75 "[..] This tempest will not giue me leaue to ponder | On things would hurt me more, [...]." 
Os seus trapos rasgados defendê-los

De tempo assim? [...]..$^{76}$

(SHAKESPEARE, 1998, p. 103-104)

No papel do louco Tom, Edgar confessa: "Deus abençoe seus cinco sentidos! Tom | está com frio! O do de, do, de, do, de. Deus o livre de | pés de vento, estrelas que explodem e mau olhado!".77 (SHAKESPEARE, 1998, p. 105)

Diante da tempestade que não cede, o Bobo resume a impotência do ser humano sob a ofensiva da natureza: "Essa noite fria está nos transformando todos em bobos e loucos". (SHAKESPEARE, 1998, p. 106) ${ }^{78}$ Como um eco definitivo de tal assertiva, logo Lear arrancará as próprias roupas. E, no momento seguinte, surge Gloucester trazendo consigo uma tocha. Além de objetivamente materializar a noite, com a introdução do artefato, Shakespeare o faz no instante que deseja revelar na cena a sensatez corporificada em Gloucester, a racionalidade, a iluminação, anunciada pelo Bobo:

Por favor, Vovô, se acomode; a noite está muito ruim Para se nadar. Um foguinho assim nesse campo todo é como coração de devasso velho: uma fagulhazinha à toa, e todo o resto do corpo gelado. Olhem só: lá vem um foguinho que anda. ${ }^{79}$ (SHAKESPEARE, 1998, p. 107)

A lealdade e a razão são como que trazidas por Gloucester que - diante do próprio filho que perseguiu e abandonou - entra sustentando uma tocha e revela a contradição de parecer cego, incapaz de julgar a verdade e, simultaneamente, de manter sua devoção ao Rei:

$$
\begin{aligned}
& \text { Gloucester - O quê? Não tem sua Graça companhia melhor? } \\
& \text { Edgar - O Príncipe das Trevas é um cavalheiro; é chamado de } \\
& \text { Modo e Mahu. } \\
& \text { Gloucester - Nossa carne, senhor, ficou tão vil, }
\end{aligned}
$$

\footnotetext{
76 "[...] Poore naked wretches, where so ere you are | That bide the pelting of this pittilesse storme, | How shall your House-lesse heads, and vnfed sides, | Your lop'd, and window'd raggednesse defend you | From seasons such as these? [...]."

77 "[...] Blisse thy fiue Wits, Toms a cold. O do, de, do, de, do, de, | blisse thee from Whirle-Windes, Starre blasting, and ta- | king, do poore Tom some charitie, whom the foule Fiend | vexes."

78 "This cold night will turne vs all to Fooles, and | Madmen."

79 "Enter Gloucester, with a Torch. | Prythee Nunckle be contented, 'tis a naughtie | night to swimme in. Now a little fire in a wilde Field, | were like an old Letchers heart, a small spark, all the rest | on's body, cold: Looke, heere comes a walking fire."
} 
Que odeia o que a gerou.

Edgar - O Pobre Tom está com frio.

Gloucester - Venha comigo. Meu dever não pode

Aceitar o que mandam suas filhas;

Embora ordenem que eu tranque as portas,

Mesmo assim eu ousei vir procurá-lo

E levá-lo onde há fogo e alimento [...]. ${ }^{80}$

(SHAKESPEARE, 1998, p. 109)

Encaminhando o final da cena 4, ele mesmo diz: "[...] pra falar a verdade, | a dor me ensandeceu. Que noite é esta [...]" ${ }^{81}$ (SHAKESPEARE, 1998, p. 110) Essa, então, é a tempestade com a qual a luz há que lidar na construção espetacular: uma tormenta que leva o homem à loucura. Ainda que determinado leitor possa transitar impunemente por tais momentos, ou que, para outro, eles não pareçam relevantes, sua presença é definitiva para a construção da visualidade da cena. A atmosfera é consistentemente sustentada, durante todo o ato, através de tais inserções, que asseguram sua efetivação no ambiente da ação.

Shakespeare, portanto, cultivava interesse menor pelo leitor "absoluto", quero dizer: aquele que se restringe aos caracteres impressos numa página. Seu esforço voltava-se para o público, na sua condição de agente integrante da práxis cênica, sendo por ela provocado, compartilhando com seu imaginário a corporificação da realidade teatral.

Ao concluir o presente capítulo, é importante registrar a particularidade que une Victor Hugo e Shakespeare, precisamente no que se refere à tempestade. Hugo era também pintor e incluiu as tormentas como tema de sua obra. Ainda que tal particularidade não seja objeto da abordagem em curso, vale o seu registro (Figura 8). Há, inclusive, propostas de conexões do surrealismo com sua pintura, o que indica atenção para a vertente plástica de sua produção artística. A obra de Hugo pode, portanto, ser associada às conexões entre a literatura e as artes visuais.

80 "Glou. What, hath your Grace no better company? | Edg. The Prince of Darkenesse is a Gentleman. Modo | he's call'd, and Mahu. | Glou. Our flesh and blood, my Lord, is growne so | vilde, that it doth hate what gets it. | Edg. Poore Tom's a cold. | Glou. Go in with me; my duty cannot suffer | T'obey in all your daughters hard commands: | Though their Iniunction be to barre my doores, | And let this Tyrannous night take hold vpon you, | Yet haue I ventured to come seeke you out, | And bring you where both fire, and food is ready. | Lear. First let me talke with this Philosopher, | What is the cause of Thunder?"

81 "[...] true to tell thee, | The greefe hath craz'd my wits. What a night's this?" 